\title{
The Troika in its own words: responding to the politicisation of the southern European crises
}

\section{Tiago Moreira Ramalho}

To cite this article: Tiago Moreira Ramalho (2020) The Troika in its own words: responding to the politicisation of the southern European crises, Journal of European Integration, 42:5, 677-693, DOI: 10.1080/07036337.2020.1792464

To link to this article: https://doi.org/10.1080/07036337.2020.1792464

曲 Published online: 19 Aug 2020.

Submit your article to this journal $₫$

凹 Article views: 330

Q View related articles $\widetilde{ }$

View Crossmark data \lceil

4 Citing articles: 3 View citing articles 


\title{
The Troika in its own words: responding to the politicisation of the southern European crises
}

\author{
Tiago Moreira Ramalho \\ Centre for European Studies and Comparative Politics, Sciences Po, Paris, France
}

\begin{abstract}
The 'post-functionalist' view that growing politicisation constrains further integration ('constraining dissensus') occupies a prominent place in contemporary European studies. However, in the case of the euro crisis, we observe a rise in contentious politics concomitant with a deepening of EU integration, namely in the areas of economic governance. This paper argues that the intervention of the 'Troika' in the struggles over the framing of the southern European crises is a key to this puzzle. The analysis of over 1200 public declarations produced by the three institutions from 2009 to 2016 shows that the Troika actively 'responded' to processes of heightened politicisation, reproducing the dominant crisis narrative of the southern European periphery and making the case for the adequacy and inevitability of austerity. The Troika's success in framing the euro crisis as a result of domestic failure and moral hazard contributed to the legitimation of further integration of European economic governance.
\end{abstract}

\section{KEYWORDS}

Economic crises; euro crisis; discourse; legitimacy; politicisation; Troika

The latest developments in European economy, not least in and around Greece, have shown that there is a pressing and urgent need to strengthen economic policy coordination. Olli Rehn (2010)

\section{Introduction}

Contemporary European studies are strongly influenced by the 'post-functionalist' hypothesis according to which increased politicisation of the European Union results in a 'constraining dissensus' to further integration (Hooghe and Marks 2009; Kriesi 2016; Wilde 2011; Zürn 2016). The euro crisis presents one of those instances of heightened politicisation of the EU (Kriesi and Grande 2016). In southern Europe, in particular, the euro crisis generated a pronounced wave of contention (Della Porta 2015). However, while the post-functionalist hypothesis would predict that intensified politicisation would generate increasing constraints on further integration, we observe the opposite in this period. National economic policies were further coordinated through the European Semester (Verdun and Zeitlin 2018); new directives on fiscal policy were enacted and the Fiscal Treaty was ratified (Laffan and Schlosser 2016); and the European Union expanded its credit facilities, having the European Stability Mechanism

CONTACT Tiago Moreira Ramalho tiago.moreiraramalho@sciencespo.fr 
in place by 2012. The euro crisis propelled the EU to grow its reach into Member States' domestic policy-making (De La Porte and Heins 2016).

This configuration raises an apparent puzzle that speaks directly to the research agenda of the special issue: how can we understand a process of deeper integration occurring alongside heightened politicisation during a crisis? According to Kriesi and Grande (2016), if we understand politicisation as a massification of growing polarisation over an increasingly salient issue, the euro crisis was not as politicized as other moments of integration crisis. However, as the authors indicate, their analysis focuses exclusively on 'creditor' countries (see Pérez 2019), leaving aside the most negatively affected political economies (Kriesi and Grande 2016, 242). The politicisation of the euro crisis was indeed rooted in a political conflict amongst creditor and debtor countries (Leupold 2016). And thus, the observation that contention in creditor countries was mild does not seem to solve the puzzle over how increased politicisation can occur alongside increased integration. Rather, it seems to hint at the importance of understanding 'varieties of politicisation' and varieties in the consequences of politicisation depending on the countries in which it occurs (Leupold 2016; De Wilde, Leupold, and Schmidtke 2016).

A second potential solution for the apparent puzzle is provided by the neo-functionalist hypothesis that politicisation was curbed through delegation of the crisis management to supra-national institutions (Schimmelfennig 2014). Indeed, the management of the euro crisis, and especially of the manifestations of this crisis in the southern European countries, was to a large extent delegated to the 'Troika' of European Commission (EC), European Central Bank (ECB), and International Monetary Fund (IMF) (Henning 2017). And it is hard to disentangle the action of the Troika in the context of the euro crisis and the specific steps of the austeritybiased European integration that occurred during the period. Yet, this view seems to strike a contradictory chord. For it is hard to understand how the delegation of the crisis management to European agencies would result in and of itself in a new form of 'permissive consensus' around European integration. The expectation might indeed be that European institutions would be the object of ensuing processes of contention (Statham and Trenz 2015, 297). The credibility of this hypothesis depends on an opening of the black box of 'delegation' in order to understand what delegation does exactly.

The article's main hypothesis is that the Troika contributed to the deepening of EU integration during the euro crisis, but not because it removed the issue from the political sphere (see Hay 2007). As a cursory overview of social movements literature focusing on the period shows, the Troika was a fundamental 'target' of the politicisation process (Accornero and Pinto 2015). Rather, the role of the Troika was one of the 'master-framer' of the euro crisis, especially in its manifestations in southern Europe. The expertise and resources mobilized by the Troika during the period gave it a particular advantage in the framing contests (Hart 1993) over the euro crisis and thus provided a strong legitimation for the austerity-based crisis management paradigm and the crisis narratives in which it was grounded. The dominant understanding of the euro crisis as a crisis of 'moral hazard' allowed for a strong rhetorical articulation with the 'necessity' to furthering EU integration.

In order to explore this hypothesis, the paper analyses the way in which the Troika's discourse on the crises of the southern European countries evolved. It will investigate, on the one hand, the timing and repertoires of discourse production during the period and, on the other, the substance of those discourses. This empirical strategy complements the typical methodological approach of recent politicisation studies, which have for the most 
part focused on large corpora of mass printed media in different European countries. The data mobilized for this analysis consist of all the official declarations produced by the three institutions, as well as the Eurogroup, about Greece, Portugal, and Spain between 2009 and 2016. Focusing on the three countries provides a larger corpus, which can increase the robustness of the analysis, but also some degree of variance between higher politicisation (Greece) and relatively lower (Portugal and Spain). The data were retrieved by searching for mentions of any of the three countries in the online archives of the IMF, the ECB, and the DG ECFIN of the EC. A total of 1283 documents were compiled. These were coded by their type and origin and all mentions of each one of the countries were counted. On the other hand, a randomly selected sample of 234 documents was analysed qualitatively (Fairclough and Fairclough 2013) in order to capture the substance of the discourse of the Troika on these countries, exploring the ways in which the three institutions construed the euro crisis and the appropriate ways of responding to it, as well as the articulation of the discourses on the crisis and integration.

Throughout the period it is possible to observe that the different institutions produced discourse that followed patterns of heightened politicisation at the domestic level in southern Europe, be it in terms of timing, repertoire, or intensity. Mentions of Greece in the Troika's discourse largely surpass mentions of either Portugal or Spain, showing some adaptability to varying degrees of politicisation. Moreover, the Troika, albeit not a fully unified actor, pushed for a broadly coherent and consistent view of the southern European crises, according to the following scheme: crises were the result of domestic failure; hence, austerity and structural reforms were unavoidable; if the programmes did not bear fruit, it was because governments lacked 'ownership'; hence programme failure was, too, domestic failure. The Troika played a political, indeed ideological role, responding to the increase in contentious politics in the different countries while presenting the euro crisis as one of moral hazard. These institutions thus contributed to the taming of the 'constraining' effect of the 'dissensus' around the euro crisis in southern Europe.

The article is structured as follows: The next section provides an overview of the euro crisis, the response to it, and the creation of the Troika. The following section focuses on the patterns in timing and repertoire of the Troika's discourse. Section 4 explores the substance of the discourse. Section 5 discusses the articulation of the Troika's discourse on the crisis and the case for deeper integration. The final section concludes.

\section{Making and responding to the euro crisis}

As the editors of the special issue argue in the introductory paper, economic crises are socially construed. In the adequately concise formulation provided by Mark Blyth $(2002,9)$, 'what constitutes an economic crisis as a crisis is not a self-apparent phenomenon.' The narrative struggle over the causes of the crisis is therefore critical for the definition of the type of response that should be pursued. This gives centrality to political discourse in the study of the making and tackling of economic crises (Hay 2016; Schmidt 2008). This section's aim is to explore the early processes of the narrative construction of the euro crisis, with special emphasis on the southern European crises, as well as the definition of crisis response policies. These elements are key for us to understand the constitution of the Troika and its relevance in the process of managing the crisis and, crucially for our purposes, in the furthering of European integration. 


\section{The narrative construction of the southern European crises}

In the Fall of 2009, the Greek government announced that the country had misreported national statistics, and that the fiscal situation was more negative than anticipated. The outbreak of the Global Financial Crisis in 2008 had generated a number of financial pressures in Europe: Ireland and Spain saw their real estate bubbles bursts, and a few countries of the Eastern periphery needed bailouts from the EU, the IMF, and the World Bank (Tooze 2018). However, the announcement by the Greek government, and the reaction that ensued, generated a decoupling of the 'euro crisis' from the broader, indeed global financial turmoil. The Greek crisis was rapidly construed, both by domestic and foreign actors, as a result of the accumulation of poor economic policy, corruption, and overall 'backwardness' (Kouki and Liakos 2015; Kutter 2014). This became the dominating frame of the different crises of the euro crisis. Speaking to the European Policy Center in April 2010, EU Commissioner Olli Rehn argued that 'Member states did not use the good times to reduce the public debt. Macroeconomic imbalances were neglected' (Rehn 2010). Progressively, the credit rating of several countries of the Eurozone periphery was downgraded by the main rating agencies, and risk premia on the sovereign bonds rose to unprecedented levels since the establishment of the monetary union. The risk differential between the 'core' and the 'periphery' of the euro area further informed the narrative of domestic failure. The discourses on the euro crisis in the European public sphere became dominated by a dichotomy between thrifty northerners and profligate southerners (Matthijs and McNamara 2015).

\section{Managing the euro crisis: bailouts in exchange for austerity}

From its earliest stages, the policy response pushed by the European institutions and partners for Greece was some variant of austerity (Blyth 2013; Karyotis and Gerodimos 2015). In early 2010, a strong austerity turn followed the 'Keynesian' response to the Global Financial Crisis; yet, the rise in sovereign bond spreads was not substantially curbed. Debt restructuring was rejected as a viable policy option both at the domestic and European levels. ECB President Jean-Claude Trichet, in particular, was vocal about his rejection of debt restructuring as well as of an interventive role for the bank in the sovereign bond market (Saltmarsh 2010). The first months of 2010 were marked by what the Financial Times termed 'constructive ambiguity': European policy-makers would argue publicly about the need, adequacy, and feasibility of financial support to Greece, while the Greek government would signal 'cooperative' behaviour through the implementation of an austerity agenda (Hope 2010). In spite of its public divisiveness, the members of the Eurogroup, along with the ECB and the IMF agreed to a financial support package in the Spring of 2010, in exchange for strict conditionality. The first Greek bailout was followed by the ones in Ireland, later in 2010, in Portugal in 2011, in Spain in 2012, and in Cyprus in 2013 - as well as by the second and third Greek bailouts, in 2012 and 2015, respectively. In all cases, the foreign funds and monetary policy support would be provided in exchange for a comprehensive austerity plan, aimed at retrenching and 'modernizing' the state, liberalizing the economy, cutting welfare provision, and re-commodifying labour in order to achieve 'internal devaluation' (Armingeon and Baccaro 2012). 


\section{The role of the Troika in the euro crisis}

It is in the context of the European negotiations of the fiscal assistance programmes that the Troika originates. It describes the association of the EC, the ECB, and the IMF in the response to the euro crisis since the first Greek bailout. This coordination had recent precedent in the joint bailouts of Romania, Hungary, and Latvia in the aftermath of the Global Financial Crisis, but the Greek bailout inaugurated a much closer association, as well as a new wave of unprecedented amounts of loans. In each one of the bailouts, the three institutions cooperated closely in the definition of the terms of conditionality - even in the Spanish case, despite the absence of IMF funding. All programmes were established broadly following IMF's practices: Memoranda were signed, establishing milestones for policy implementation, and a schedule of loans and repayments was set up.

Joint technical teams were sent quarterly by the Troika to the countries in order to evaluate the implementation of the programmes. These analyses would result in technical reports - one for the European institutions and one for the IMF. Besides the technical reports, the different actors of the Troika used other forms of public discourse. Either in direct or indirect relationship with the programmes, the Troika produced a stream of discourses in which the situation in the southern European countries was addressed. The role of those discourses in framing the euro crisis as it unfolded, as well as the process of European integration, will be the focus of the following sections.

\section{Responding to politicisation: timing and repertoires in the Troika's discourse}

The production of public discourse by the institutions of the Troika followed a pattern that can be closely linked to the processes of heightened politicisation of the euro crisis in southern Europe. This sensitivity of the Troika to the political developments in the three countries contributes to the corroboration of our hypothesis that these institutions played a central role in the ongoing struggle over the appropriate framing of these crises. The analysis of the corpus of the 1283 documents retrieved from the public online archives of the ECB, IMF, and EC provides strong empirical groundings for the idea that, through discourse, the Troika 'responded' to the varying degrees of domestic politicisation occurring in each one of the countries. The treatment of the documents shows that (i) these countries were mentioned more, in absolute terms, broadly in accordance with the patterns of contentious politics observed in the literature; (ii) the repertoires of discourse in which the countries were mentioned can, too, be linked to those patterns; and (iii) in spite of their autonomy in discourse production, the trends in the different institutions are broadly similar.

In each document, the number of mentions of each one of the countries was calculated. The results were aggregated by quarter and are presented in Figure 1. Peaks in the frequency of mentions are closely linked with major political developments, especially with those in Greece. In the second quarter of 2010, during the negotiations of the first Greek bailout, mentions of the three countries, but especially of Greece, rose sharply. From this high point, mentions decreased substantially until 2011, when the Portuguese bailout was negotiated. This marked a starting point for a 'cycle' of discourse-making that saw its peak in 2012, when the three countries were concomitantly under some form of 


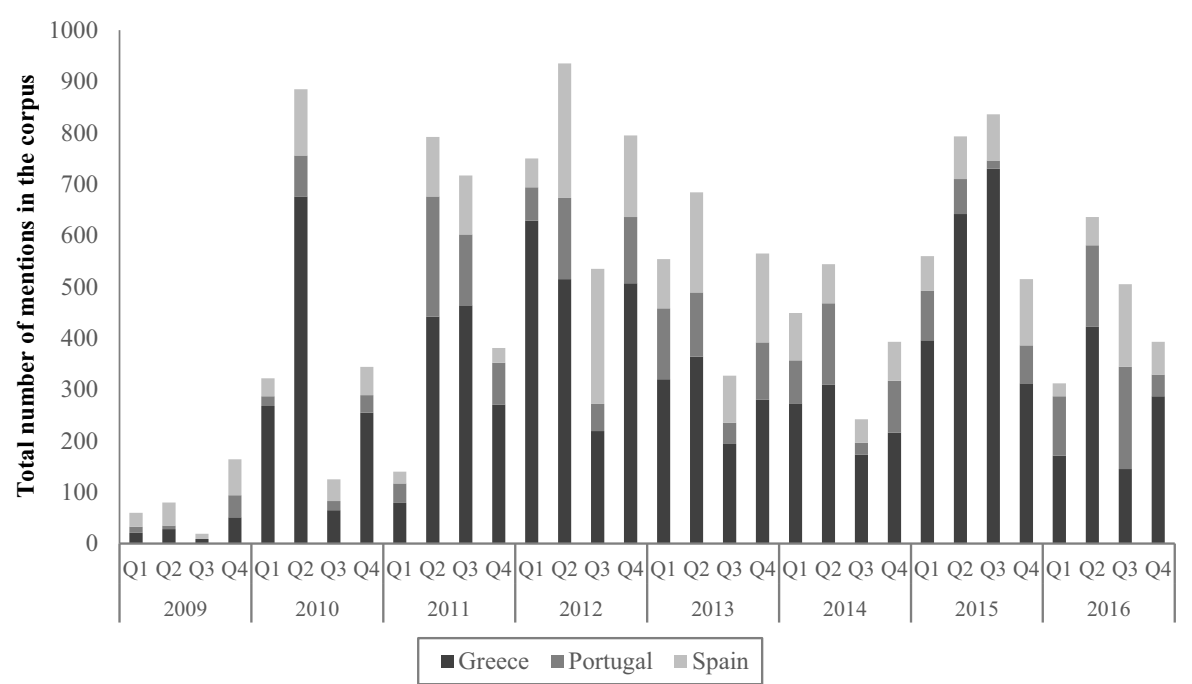

Figure 1. Mentions of Greece, Portugal, and Spain in the Troika's discourse. Data sources: Online archives of the IMF, the ECB, and the EC. Author's computations

external financial assistance, and which decreased progressively towards the final stages of the Portuguese and Spanish programmes, in 2014. This trend follows with remarkable accuracy the one identified by Kriesi and Grande (2016), even though the latter focuses on the politicisation of the euro crisis in mass media in 'creditor' countries. At the end of 2014, a new inflexion point occurs and a substantial growth in mentions, especially of Greece, is observed during 2015. The latter occurs alongside the rise of SYRIZA into government office in Greece, and the 'challenge' posed by the Tsipras-led government of the bailout strategy in Greece.

The patterns in the production of discourse on the southern European countries by the Troika during the period allow for two main observations. Firstly, the Troika's discourse on each one of the countries was clearly shaped by the processes of politicisation of the euro crisis at both the domestic and transnational levels. The Troika's discourse was indeed part of that politicisation process. The second observation gives further support to that idea: during the whole period, more discourse was produced on Greece than on any of the other two countries. A potential explanation for the difference could be that Greece's programmes lasted for longer than the others; however, that would not explain why, even in the period spanning from 2011 to 2014, when the three countries were simultaneously under financial assistance, the disproportion remained. A more persuasive cause for the disparity lies in the variation in politicisation of the euro crisis in the three countries. Indeed, the impact of the crisis in Greece was much more severe than in the other two countries, which contributed to an extent to the higher level of contention in Greece than in the Iberian countries throughout the period (Della Porta 2015). Moreover, the crisis management approach to Greece formed a template for the general response to the euro crisis - and for the processes of European integration that ensued from it. Hence, to discuss the Greek crisis during this period was, at least indirectly, to discuss the euro crisis and the European response to it. 
The evolution in the repertoires of discourse production further illuminates the role of the Troika in the politicisation process of the euro crisis. All documents in our corpus were coded by type, according to six main categories: speeches, statements, press documents, technical documents, official letters, and conference call transcripts. The vast majority of the corpus fits one of the first three categories. Documents were coded as 'speeches' when they consisted of a public intervention made by a specific individual in one of the institutions, such as Olli Rehn's interventions in the European Parliament. As for 'statements', these are typically shorter documents that express the view of a collective actor, such as the many statements produced by the Troika, jointly or otherwise, on the evolution of the implementation of the programmes in the countries. 'Press' documents include press briefings hosted by the institutions, as is common at both the ECB and the IMF, as well as interviews and other types of interaction with the press. The remaining three types of documents ('technical documents', 'conference call transcripts', and 'official letters') were broadly less predominant. The use of each type of document by the Troika during the period is depicted in Figure 2.

As observable in the graph, all types of documents present a similar trend. From 2010 to 2014 there is one 'cycle' of discourse production, peaking around 2012, and in 2015 there is a new peak, especially in press documents, but also in speeches. Once more, these trends follow the processes of politicisation of the crisis. Certainly, the pattern in the publication of statements is somewhat expected: towards 2012, an increasing number of bailouts were negotiated, and they were progressively ended until 2014. However, neither the evolution of press documents, nor the evolution of speeches in which the three southern European countries are mentioned can be explained in the same way. The peak in 2015 is particularly striking, for it was a moment of clear collision in the context of the

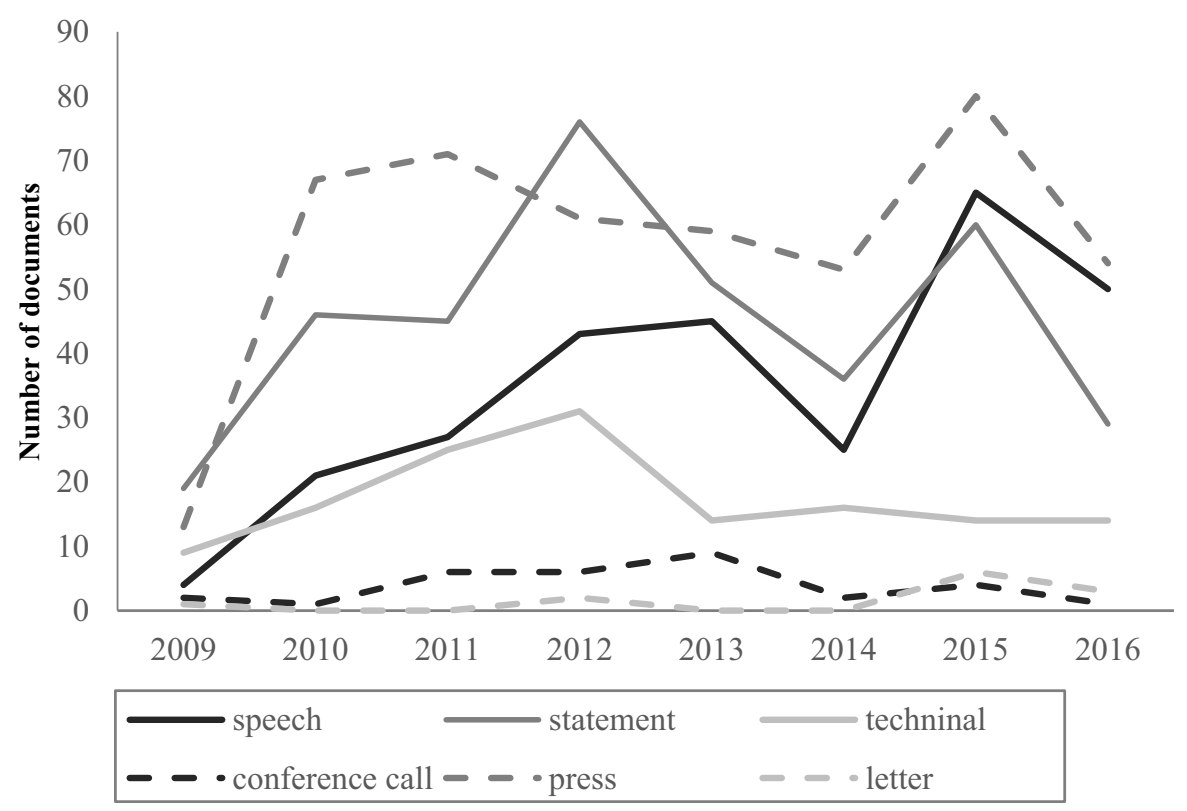

Figure 2. The evolution of the Troika's declarations by type. Data sources: Online archives of the IMF, the ECB, and the EC. Author's computations 
Eurogroup between Greece and the creditor countries and institutions. The increase in support for SYRIZA in Greece led the Troika to step largely outside of its so-called 'technocratic' role. For instance, in January 2015 alone, ECB Executive Board member Benoît Coeuré gave five different interviews, in which the Greek election was discussed. Interviews with the European press are not an uncommon occurrence in the case of the ECB. In our period, a total of 95 interviews with important outlets were found in the institutions' online archive. However, the total of 31 interviews given in 2015 alone shows some level of disproportion.

Of the institutions that form the Troika, the ECB could be expected to be the least involved in politicisation processes. The political economy of central banks has for long shown how these bodies became increasingly 'independent' from the arena of politics - or, at least, from the type of pressure that democratic elections might otherwise generate (Hay 2007, 113-18). Moreover, recent literature on the euro crisis has shown how the Troika, in spite of high levels of coordination, remained a constellation of different actors holding different, even if for the most part reconcilable, views of the crisis (Henning 2017). It becomes therefore pertinent to assess whether these different actors showed different patterns in their discourse-making.

The documents in the corpus were coded based on the authorship of the text. Besides the $I M F$, the EC, and the ECB, some documents were attributed to the Council of the European Union (typically when they consisted of statements from the Eurogroup or its President), and to the European Union Council (typically statements in the context of country summits or interventions by the President). A sixth category was created for any document produced by more than one institution, such as joint declarations by the three institutions of the Troika. The results, presented in Figure 3, show that in spite of an important difference in the 'level' of discourse production, the patterns are broadly similar across the three main institutions and

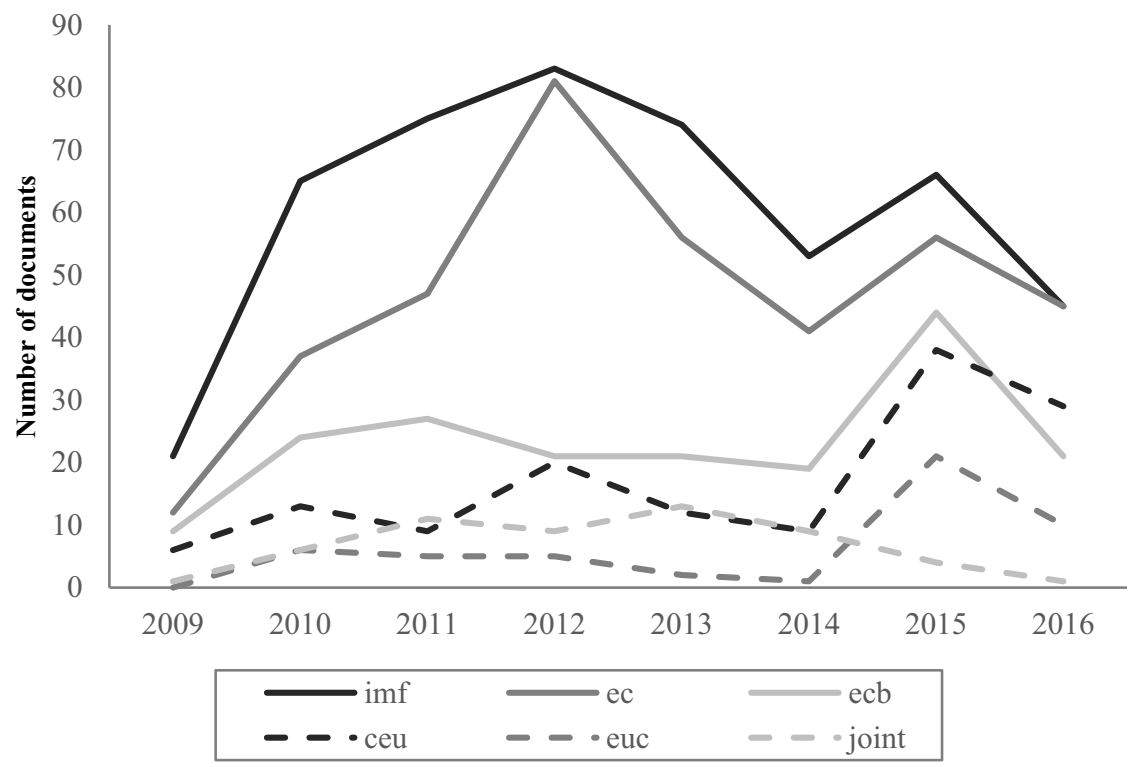

Figure 3. The institutional sources of the Troika's discourse. Data sources: Online archives of the IMF, the ECB, and the EC. Author's computations 
the CEU/Eurogroup. This is particularly the case in 2015, when all relevant actors in the Troika substantially increased the number of public declarations on the three countries. Although different parts of the Troika might be more organizationally predisposed to intervene publicly in the contentious process of crisis management, all of them show a significant level of responsiveness to politicisation processes.

The analysis of the corpus of over 1200 documents of public declarations of the Troika shows that the different institutions, either on their own or in a coordinated fashion, were highly responsive to the conflict generated around the euro crisis and its response. The less 'technical' types of discourse, namely press events and speeches were mobilized as much as the more routine-based ones, such as statements. These tendencies were shared by all institutions that constitute the Troika. This analysis, however, has not allowed us to understand what it is that the Troika conveys through this discourse production. An analysis of the substance of the discourse is necessary in order to grasp the role of these institutions in the politicisation processes of the euro crisis.

\section{Arguing the euro crisis: the substance of the Troika's discourse}

The previous section has shown that the Troika's discourse on the southern European countries followed general patterns of politicisation of the euro crisis and of contention in those societies. This section turns to the substance of that discourse. A sample of 234 documents was randomly selected for a more in-depth, qualitative analysis. Following Fairclough and Fairclough (2013), we approach these documents as instances of 'practical argumentation'. In each one of them, the institutions of the Troika mobilize their understanding of the euro crisis and of the appropriate solution to it. These documents thus form a web of argumentative texts that allows for the analytical reconstruction of the Troika's framing of the euro crisis. Close reading of the texts allowed for the definition of five main argumentative steps in the Troika's frame: the reproduction of the dominant crisis narrative; the rejection of debt alleviation as a policy solution; the promotion of austerity as inevitable; the suggestion of programme 'ownership' as critical to economic recovery; and the rejection of programme failure. The analysis shows how the Troika consistently framed the crisis as resulting from domestic failure, and thus as a crisis of moral hazard.

\section{Reproducing the dominant crisis narrative}

In a hearing at the European Parliament on the management of the euro crisis, held in 2014, EC Vice-President Olli Rehn argued that 'the structural adjustment from accumulated macroeconomic imbalances ... involve[d] difficult and often painful choices,' but that 'the responsibility must in the first place be carried by those who let these imbalances accumulate, with all their social consequences.' For the 'policies that led to the accumulation of macroeconomic imbalances fall under national responsibility' (Rehn 2014). This is a good illustration of the overall understanding of the causes of the euro crisis held by the EC and by the Troika more broadly. From the early stages of the Greek crisis, the crisis narrative mobilised by the institutions that would eventually form the Troika was one of domestically accumulated 'imbalances': the financial crisis, more than causing the economic predicaments of these political economies, was seen as revealing their underlying fragilities. 
This narrative mobilised commonplace naturalising metaphors, such as the discourse of 'contagion' (see Peckham 2013), but also a strong moral discourse, which presented the peripheral countries as 'rogue' states that did not contribute to the overall equilibrium of the European economy (Fourcade et al. 2013). The crisis narrative reproduced by the Troika was thus one of moral hazard. This is evident in Rehn's discourse on the need to build institutions 'with strong built-in disincentives for activation by making [them] so unattractive that no country would voluntarily use [them]' (Rehn 2010), but also in the widely cited statement by German Chancellor Angela Merkel, according to which crisis countries had to 'atone for past sins' (cited in Hall 2012, 368). In more or less explicit forms, this is the crisis narrative that is reproduced in the Troika discourse during the period.

\section{The anathema of debt relief}

During the euro crisis, different actors suggested forms of debt relief and several policy options 4rgained support during the period, from Eurobonds all the way to debt default (De Grauwe 2011; Matthijs and McNamara 2015; Roos 2019). Yet, the discourse of the Troika on the issue was for the most part elusive. In the documents of the corpus, the Troika officials tend not to raise the issue of debt restructuring, and only engage with it when confronted by reporters in press events.

The engagement of the Troika with the issue of debt relief tends to fall into two main responses. The first is evasion. For instance, IMF spokesperson Caroline Atkinson, when asked about the position of the institution on the restructuring of Greece's debt, replied that 'our program was designed on the basis of the government's firm commitment to honour its debt obligations and guarantees and that still holds' (International Monetary Fund 2011). When asked a similar question about Portugal, ECB President Mario Draghi gave a similar answer: 'We have confidence that the program countries are taking appropriate actions and that the targets of their programs are achievable and realistic' (Draghi 2012). The second form of engagement is a clearer rejection of debt restructuring as a viable option. A good illustration comes from ECB President Jean-Claude Trichet, who replied to a journalist at a press conference that ' $[\mathrm{a}] \mathrm{s}$ regards the question of restructuring, we consider that what is important is, again, to do the job, to adjust. There is a plan, and we call for the implementation of the plan! That's all to say, full stop!' (Trichet and Vítor 2011). As the crisis unfolded, despite different policies of debt relief being adopted, debt relief remained anathema. Restructuring of sovereign debts was construed as an option to avoid at all costs.

\section{The inevitability of fiscal consolidation and structural reforms}

While the Troika's public discourse reveals strong reluctance to engage with debt relief as a policy, it unambiguously pushes for 'fiscal consolidation' and 'structural reforms' as the only possible way out of the crisis. This promotion was argued in close articulation with the crisis narrative that dominated the Troika's discourse, as discussed above. A good illustration comes from a speech by Olli Rehn in 2012:

I [am] well aware how hard the present moment is for the people of Spain. The same is true of Portugal, Greece and many of our other member States where macro-economic imbalances had been building up for many years by the time the crisis hit these countries and 
their people. Correcting these imbalances was something that could not be avoided (Rehn 2012).

Although the analysis of the corpus presents some variance regarding the expected effects of these policies, a combination of fiscal consolidation and structural reforms dominates the Troika's management of the crisis. As Mario Draghi put it in an interview to the Wall Street Journal:

There was no alternative to fiscal consolidation, and we should not deny that this is contractionary in the short term. In the future there will be the so-called confidence channel, which will reactivate growth; but it's not something that happens immediately, and that's why structural reforms are so important, because the short-term contraction will be succeeded by long-term sustainable growth only if these reforms are in place (Draghi 2012).

As the crisis evolved, the Troika's case for the combined inevitability of budgetary cuts and liberalising 'structural reforms' became increasingly intertwined. Poor economic performance was attributed not to austerity per se, but to the inability to appropriately put in place 'growth-enhancing structural reforms', or, as the Troika often put it, to the lack of 'programme ownership'.

\section{The relevance of 'programme ownership'}

As programme implementation unfolded, it became increasingly apparent that the expected economic gains of austerity were not being realized and that the economic performance of the 'programme countries' varied considerably. For example, Greece's national income was in 2012 over $20 \%$ lower than the pre-crisis peak. The Troika attributed a substantial part of these developments to lack of 'programme ownership'. The three institutions of the Troika spoke in unison:

I think, as we have said consistently, and I think the European partners have said this consistently, the ownership of that program by the Greek government is essential. (International Monetary Fund 2013)

[T] he ownership of the programme by the beneficiary Member State is always key for a successful economic turnaround. (Rehn 2014)

The more ownership there is at the national level, the more it can be demonstrated that reforms will be maintained and the less a precautionary security mechanism is needed. (Praet 2014)

Programme ownership remained a key element of the Troika's framing of the crisis until the end of the period, even if some countries were seen as more wholeheartedly for austerity than others. These distinctions were notably apparent with the rise to power of Syriza in Greece, in January 2015.

Programme 'ownership' became as necessary as the actual implementation of fiscal consolidation and of structural reforms. Economic recovery hinged, according to the Troika, on full ideological and discursive appropriation, at the national level, of the programmes. The relevance of 'ownership' constitutes the final knot in the Troika's framing of the euro crisis: the crises are a result of domestic failure; hence, austerity and structural reforms are inevitable; if the programmes don't bear fruit, it is because governments did not own them enough; hence programme failure is domestic failure. 


\section{The rejection of programme failure}

The macroeconomic targets of the programmes regarding growth, unemployment, or debt were generally missed, and the economic situation of the countries under assistance deteriorated more severely than publicly anticipated. The economic performance of Greece, in particular, raised the question of programme failure. The Troika, however, rarely addressed the issue. When confronted by journalists, Troika officials consistently refused to acknowledge the possibility of failure.

As the second Greek bailout was being negotiated, IMF's spokesperson David Hawley replied to a journalist that '[c]ertainly we do not accept that the first program failed' (Hawley 2012). The debate over programme design failure was later heightened by a technical report authored by IMF economists arguing that the recessionary effects of austerity (fiscal multipliers) had been underestimated (International Monetary Fund 2012). Yet, when asked by a journalist whether 'there [were] any mistakes ... that [she] wouldn't like to be reiterated ... in the future for Greece,' Lagarde replied: 'I'm not personally especially interested in trying to rewrite history or blame anybody or point the finger' (Lagarde 2013).

As discussed above, the economic predicament of the different countries, and especially of Greece, was mostly attributed to lack of 'ownership'. For instance, when asked by a Portuguese newspaper whether Greece had been the ECB's 'biggest failure', Executive Board Member Paul Praet (2014) replied that 'Greece is the biggest failure of Greece itself ... [t]he big problem in Greece is Greece itself and the difficulty that its society has to unite.'

There were instances, during the period, of programme 'evaluation' carried both by the European Parliament (Karas and Ngoc 2014) and by the Internal Evaluation Office of the IMF (International Monetary Fund 2016), which presented important critiques to the operation of the Troika. Yet, the discourse of the Troika officials remained consistent in the rejection of programme failure. The bad fortunes of the southern European political economies were not to be attributed to poor policy design, but to poor policy implementation.

\section{'Moral hazard' and the discourse of integration}

The previous two sections show how the Troika's discourse on Greece, Portugal, and Spain followed the patterns of politicisation of the euro crisis in these countries and how it consistently framed these crises as resulting from domestic failure. The views of the Troika did present some variance across institutions and in time: the desirability of debt restructuring or the impact of fiscal consolidation are cases in point. However, throughout the euro crisis, there was consistency in a set of core ideas about the causes of the crisis as well as the broad crisis management approach. Regardless of differences in rhetorical strategies, these form the ideological basis on which the different actors of the Troika built their arguments about what to do, what Fairclough and Fairclough (2013) term 'practical argumentation'. At a fundamental level, the Troika's framing of the euro crisis presented it as resulting from moral hazard: uncooperative Member States pursued poor economic policies that led to an accumulation of 'imbalances'. The Troika's discourse further presented both bailouts and 'punitive' austerity as inevitable. The 'moral hazard' frame pervaded domestic politics, with national elites in both 'creditor' and 'debtor' countries adopting it in their discourses (Borriello 2017; Séville 2017). Moreover, it informed the Troika's discourse on further European integration. 
The successful framing of the euro crisis as a result of uncooperative behaviour on the part of 'rogue' Member States opened a window of opportunity for the articulation of a strong case for further European integration. As Rehn (2010) put it at the time of negotiating the first financial assistance programme to Greece: 'The latest developments in the European economy, not least in and around Greece, have shown that there is a pressing and urgent need to strengthen economic policy coordination.' The consistency of these ideas in Rehn's discourses shows that expanding the EU institutions' power over economic policy was a clear goal, and that its pursuit required ideological work against the backdrop of rising Euroscepticism. As he would argue at the European Parliament in the summer of 2011, 'we must look further ahead and focus on the long-term implications of the crisis for the European project ... [D]eeper economic integration will have to be part of the answer, despite current trends that appear to go in the opposite direction' (Rehn 2011). Although these positions were articulated by Rehn during his speeches, they were also made clear in the Commission's more technical documents. For instance, in a technical memo about the banking union, it is stated that 'the Commission has been pushing for deeper economic integration as one of the remedies to the current crisis' (European Commission 2012).

The EC was not alone in purporting the nexus between a 'moral hazard' narrative of the crisis and the need to further European integration. The IMF, too, argued publicly for the need to 'complete' the integration process. In 2012, Deputy Managing Director Nemat Shafik made a speech at the Brussels Economic Forum, whose core ideas were aligned with the Commissions' (Shafik 2012). According to Shafik, '[m]arkets are worried about the ability and commitment of some European governments to rein in fiscal deficits, contain the crisis, and revive growth'. The IMF, therefore, argued for 'macroeconomic policies to support demand in the near term, and further progress in structural reforms to raise longterm growth and complete the process of European integration.' Once more, the dominant crisis narrative around the untrustworthy Member States was articulated with a need for deepening EU integration - indeed, to 'complete' it. Shafik went further, suggesting that governments had a duty of 'explaining the rationale of reforms to the public', for ' $[\mathrm{l}] \mathrm{osing}$ public support now, at this critical juncture, risks negating the efforts of the past 2 years, and will set Europe back'. Governments were thus exhorted to appropriate and push forward the Troika's arguments ('rationale') about the management of the euro crisis, presenting them as 'necessary'. Arguing that 'it is time to accept necessity', Shafik quoted Jean Monnet, 'another of Europe's great statesmen': 'People only accept change when they are faced with necessity, and only recognize necessity when a crisis is upon them'. There is no particular difference between this exhortation to European governments and the ones put forth by different actors within the EU bureaucratic apparatus.

In the corpus of documents analysed for this article, the discourse of the ECB on furthering EU integration is more subdued than those of the EC or the IMF. Asked whether the ECB would 'do something to help buy time' if 'there is some progress by governments towards the fiscal union', Draghi replied that it 'would not be proper' to engage in such 'quid pro quo', and that 'these processes have their own independent legislative roots and they cannot be subject to the monetary policy-makers' decisions' (Draghi and Vítor 2012). On several occasions Draghi has commented on 'the imperfect nature of our integration at the present time' (Draghi and Vítor 2015). And although the case for further integration was not made as forcefully as it was by EC or the IMF officials, there was a general alignment around its 'necessity'. 
Furthering European integration was thus presented in the Troika's discourse as a corollary of the general framing of the euro crisis. The imperatives of 'solidarity' required, so the argument went, a logic of guarantees that could prevent further 'moral hazard'. As Rehn argued, the EC's 'guiding principle in rebuilding the EMU is that any steps towards more solidarity and mutualisation of risk should be combined with increased responsibility and further sharing of budgetary sovereignty. That implies deeper integration of decision-making, as well as commensurate steps towards a political union and increased democratic accountability' (Rehn 2013). The Troika's discourse was not only fundamental for the framing of the euro crisis as one of moral hazard, but also for an understanding of 'more Europe' as the necessary avenue towards economic stability and prosperity.

\section{Conclusion}

As Statham and Trenz (2015) argue, the post-functionalist view of European integration suggests that politicisation is 'almost synonymous with increasing "Euroscepticism"' (2015, 288). As much seems to be not too surprising, if the process of further integration becomes more politicised, it is likely that part of that politicisation derives from growing Euroscepticism - or at least from an increase in the expression of Euroscepticism. What is problematic, however, is the assumption that politicisation prevents further integration. As the case of the euro crisis shows, the heightened politicisation of the EU during the period coincided with a substantial expansion of the powers of the EC and with the creation of new institutions of economic governance. This 'puzzle', however, is only apparent due to the unwarrantedly deterministic expectations of most post-functionalist literature. In effect, the 'politicisation' of EU integration should rather lead us to expect an insertion of the issue within the realm of political choices, and thus of contingency (Hay 2007).

During the euro crisis, as this article has shown, the heightened politicisation observed throughout Europe, and especially in the most affected countries, occurred alongside, and in interaction with, the mobilization of discourses by the institutions of the Troika aiming at producing and reproducing a dominant frame for the crisis. According to the latter, the different crises of the euro crisis were the result of poor economic policies pursued by the uncooperative Member States. This narrative provided the grounds for the articulation of the case for, on the one hand, deep austerity at the country-level, aimed at 'correcting' the accumulated 'imbalances', and, on the other, reinforced economic governance at the EUlevel. The politicisation of the euro crisis should not be understood as a rock on the functionalist path of ever-tighter integration, but as a struggle over the appropriate way of understanding the crisis and the adequate response to it. The successful framing of the crisis as a crisis of moral hazard gave strength to the idea that deeper integration was a 'necessity'. The link between the two is consistently made by the different actors of the Troika throughout the period.

The apparent 'paradox' of the euro crisis in the recent scholarship on European integration, therefore, pushes integration studies to abandon the 'mechanistic' logic according to which more politicisation causes less integration. This 'post-functionalist' assumption has led the literature to largely focus on an operationalization of politicisation that defines it as a product of increased salience with a combination of massification and polarization of debates (Kriesi 2016; Wilde 2011). Yet, the case of the euro crisis shows that the study of politicisation of the EU would benefit from the incorporation a more contextual, qualitative 
analysis of the competing frames that politicisation generates. In the case of the euro crisis, that effort amounts to an analytical 're-politicisation' of the Troika, and to understanding the actions and words of the actors and institutions that constitute it as themselves 'political'.

\section{Acknowledgements}

The author would like to thank Benedetta Voltolini, Colin Hay, James Wood, Michal Natorski, Tiago Carvalho, and the two anonymous referees from the Journal of European Integration for their helpful comments on earlier versions of this paper. The usual disclaimers apply.

\section{Disclosure statement}

No potential conflict of interest was reported by the author.

\section{ORCID}

Tiago Moreira Ramalho (D) http://orcid.org/0000-0003-1015-4268

\section{References}

Accornero, G., and P. R. Pinto. 2015. "'Mild Mannered'? Protest and Mobilisation in Portugal under Austerity, 2010-2013." West European Politics 38 (3): 491-515. doi:10.1080/01402382.2014.937587.

Armingeon, K., and L. Baccaro. 2012. "Political Economy of the Sovereign Debt Crisis: The Limits of Internal Devaluation." Industrial Law Journal 41 (3): 254-275. doi:10.1093/indlaw/dws029.

Blyth, M. 2002. Great Transformations: Economic Ideas and Institutional Change in the Twentieth Century. New York: Cambridge University Press.

Blyth, M. 2013. Austerity: The History of a Dangerous Idea. Oxford: Oxford University Press.

Borriello, A. 2017. "'There Is No Alternative': How Italian and Spanish Leaders' Discourse Obscured the Political Nature of Austerity." Discourse \& Society 28 (3): 241-261. doi:10.1177/ 0957926516687419.

De Grauwe, P. 2011. "Governance of a Fragile Eurozone." CEPS Working Document (346). Accessed 15 September 2019. https://papers.ssrn.com/abstract $=1898618$

De La Porte, C., and E. Heins. 2016. The Sovereign Debt Crisis, the EU and Welfare State Reform. Basingstoke: Palgrave Macmillan.

De Wilde, P., A. Leupold, and H. Schmidtke. 2016. "Introduction: The Differentiated Politicisation of European Governance." West European Politics 39 (1): 3-22. doi:10.1080/01402382.2015.1081505.

Della Porta, D. 2015. Social Movements in Times of Austerity: Bringing Capitalism Back into Protest Analysis. 1 ed. Cambridge: Polity Press.

Draghi, M. 2012. "Interview with the Wall Street Journal, Conducted by Robert Thomson, Matt Karnitschnig, and Brian Blackstone on 22 February 2012, Published on 24 February 2012." Accessed 4 March 2019. https://www.ecb.europa.eu/press/inter/date/2012/html/sp120224.en. html

Draghi, M., and C. Vítor. 2012. "Introductory Statement to the Press Conference (With Q\&A)." https:// www.ecb.europa.eu/press/pressconf/2012/html/is120606.en.html

European Commission. 2012. "Memo: Update - The Banking Union." https://europa.eu/rapid/pressrelease_MEMO-12-413_en.htm?locale=en

Fairclough, I., and N. Fairclough. 2013. Political Discourse Analysis: A Method for Advanced Students. London: Routledge.

Fourcade, M., P. Steiner, W. Streeck, and C. Woll. 2013. "Moral Categories in the Financial Crisis." Socio-Economic Review 11 (3): 601-627. doi:10.1093/ser/mwt012. 
Hall, P. A. 2012. "The Economics and Politics of the Euro Crisis." German Politics 21 (4): 355-371. doi:10.1080/09644008.2012.739614.

Hart, P. T. 1993. "Symbols, Rituals and Power: The Lost Dimensions of Crisis Management." Journal of Contingencies and Crisis Management 1 (1): 36-50. doi:10.1111/j.1468-5973.1993.tb00005.x.

Hawley, D. 2012. "Transcript of a Press Briefing by David Hawley, Deputy Director, External Relations Department, International Monetary Fund, March 22nd, 2012." https://www.imf.org/external/np/ $\operatorname{tr} / 2012 / \operatorname{tr} 032212 . h t m$

Hay, C. 2007. Why We Hate Politics. 1 ed. Cambridge, Malden, MA: Polity Press.

Hay, C. 2016. "Good in a Crisis: The Ontological Institutionalism of Social Constructivism." New Political Economy 21 (6): 520-535. doi:10.1080/13563467.2016.1158800.

Henning, C. R. 2017. Tangled Governance: International Regime Complexity, the Troika, and the Euro Crisis. Oxford, New York: Oxford University Press.

Hooghe, L., and G. Marks. 2009. "A Postfunctionalist Theory of European Integration: From Permissive Consensus to Constraining Dissensus." British Journal of Political Science 39 (1): 1-23. doi:10.1017/S0007123408000409.

Hope, K. 2010. "Greece Rejects Speculation of Bail-Out." Financial Times, Accessed 15 March 2019. https://www.ft.com/content/7504f472-fae9-11de-94d8-00144feab49a

International Monetary Fund. 2011. "Transcript of a Press Briefing by Caroline Atkinson, Director, External Relations Department, International Monetary Fund, May 26th, 2011." https://www.imf. org/external/np/tr/2011/tr052611.htm

International Monetary Fund. 2012. "World Economic Outlook, October 2012: Coping with High Debt and Sluggish Growth." Accessed 4 March 2019. https://www.imf.org/en/Publications/WEO/ Issues/2016/12/31/World-Economic-Outlook-October-2012-Coping-with-High-Debt-and-

Sluggish-Growth-25845

International Monetary Fund. 2013. "Transcript of a Press Briefing by Gerry Rice, Director, Communications Department, International Monetary Fund." https://www.imf.org/external/np/ tr/2013/tr082913.htm

International Monetary Fund. 2016. "The IMF and the Crises in Greece, Ireland, and Portugal." Evaluation Report. https://ieo.imf.org/en/our-work/evaluation-reports/Completed/2016-0728the-imf-and-the-crises-in-greece-ireland-and-portugal

Karas, O., and L. H. Ngoc. 2014. "Report on the Enquiry on the Role and Operations of the Troika (ECB, Commission and IMF) with Regard to Euro Area Programme Countries (2013/227(INI))." http:// www.europarl.europa.eu/sides/getDoc.do?pubRef=-//EP//TEXT+REPORT+A7-2014-0149+0+DOC $+\mathrm{XML}+\mathrm{V} 0 / / \mathrm{EN}$

Karyotis, G., and R. Gerodimos, eds. 2015. The Politics of Extreme Austerity: Greece in the Eurozone Crisis. 2015 ed. Houndmills, Basingstoke, Hampshire; New York, NY: AIAA.

Kouki, H., and A. Liakos. 2015. "Narrating the Story of a Failed National Transition: Discourses on the Greek Crisis, 2010-2014." Historein 15 (1): 49-61. doi:10.12681/historein.318.

Kriesi, H. 2016. "The Politicization of European Integration." JCMS: Journal of Common Market Studies 54 (S1): 32-47.

Kriesi, H., and E. Grande. 2016. "The Euro Crisis: A Boost to the Politicisation of European Integration?" In Politicising Europe: Integration and Mass Politics, edited by S. Hutter, E. Grande, and H. Kriesi, 240-276. Cambridge: Cambridge University Press.

Kutter, A. 2014. "A Catalytic Moment: The Greek Crisis in the German Financial Press." Discourse \& Society 25 (4): 446-466. doi:10.1177/0957926514536958.

Laffan, B., and P. Schlosser. 2016. "Public Finances in Europe: Fortifying EU Economic Governance in the Shadow of the Crisis." Journal of European Integration. 38 (3): 237-249. doi:10.1080/ 07036337.2016.1140158.

Lagarde, C. 2013. "Transcript of Managing Director's New Year Press Briefing." https://www.imf.org/ external/np/tr/2013/tr011713.htm

Leupold, A. 2016. "A Structural Approach to Politicisation in the Euro Crisis." West European Politics 39 (1): 84-103. doi:10.1080/01402382.2015.1081510. 
Matthijs, M., and K. McNamara. 2015. "The Euro Crisis' Theory Effect: Northern Saints, Southern Sinners, and the Demise of the Eurobond." Journal of European Integration 37 (2): 229-245. doi:10.1080/07036337.2014.990137.

Peckham, R. 2013. "Economies of Contagion: Financial Crisis and Pandemic." Economy and Society 42 (2): 226-248. doi:10.1080/03085147.2012.718626.

Pérez, S. A. 2019. "A Europe of Creditor and Debtor States: Explaining the North/South Divide in the Eurozone." West European Politics 42 (5): 989-1014. doi:10.1080/01402382.2019.1573403.

Praet, P. 2014. "Interview with Peter Praet, Member of the ECB's Executive Board, for Expresso, Conducted by João Silvestre and Ricardo Costa on 18 February 2014." https://www.ecb.europa. eu/press/inter/date/2014/html/sp140222.en.html

Rehn, O. 2010. "Reinforcing Economic Governance in Europe (Speech Delivered at the European Policy Centre, Brussels)." europa.eu/rapid/press-release_SPEECH-10-160_en.pdf

Rehn, O. 2011. "Final Report of the CRIS Committee by Ms. Berès (Speech Delivered at the European Parliament)." http://europa.eu/rapid/press-release_SPEECH-11-503_en.pdf

Rehn, O. 2012. "European Commission Memo: Press Speaking Points by Vice-President Rehn at the Eurogroup - Luxembourg 8 October." http://europa.eu/rapid/press-release_MEMO-12-758_en. htm?locale=en

Rehn, O. 2013. "SPEECH: Deeper Integration in the Eurozone and Britain's Place in Europe." https:// europa.eu/rapid/press-release_SPEECH-13-174_en.htm

Rehn, O. 2014. "Mr. Olli Rehn at the ECON Committee Hearing on the Troika Report." http://europa. eu/rapid/press-release_SPEECH-14-14_en.htm

Roos, J. E. 2019. Why Not Default?: The Political Economy of Sovereign Debt. Princeton, NJ: Princeton University Press.

Saltmarsh, M. 2010. "Trichet Says Greece Will Not Be Allowed to Default." The New York Times. Accessed 17 June 2019. https://www.nytimes.com/2010/04/09/business/global/09euro.htm

Schimmelfennig, F. 2014. "European Integration in the Euro Crisis: The Limits of Postfunctionalism." Journal of European Integration 36 (3): 321-337. doi:10.1080/07036337.2014.886399.

Schmidt, V. A. 2008. "Discursive Institutionalism: The Explanatory Power of Ideas and Discourse." Annual Review of Political Science 11 (1): 303-326. doi:10.1146/annurev.polisci.11.060606.135342.

Séville, A. 2017. "From 'One Right Way' to 'One Ruinous Way'? Discursive Shifts in 'There Is No Alternative'." European Political Science Review 9 (3): 449-470. doi:10.1017/S1755773916000035.

Shafik, N. 2012. "'Reviving Growth in Europe' - Speech to the Brussels Economic Forum, Brussels, by Deputy Managing Director Nemat Shafik, International Monetary Fund." https://www.imf.org/en/ News/Articles/2015/09/28/04/53/sp053112

Statham, P., and H.-J. Trenz. 2015. “Understanding the Mechanisms of EU Politicization: Lessons from the Eurozone Crisis." Comparative European Politics 13 (3): 287-306. doi:10.1057/cep.2013.30.

Tooze, A. 2018. Crashed: How a Decade of Financial Crises Changed the World. New York: Viking.

Trichet, J.-C., and C. Vítor 2011. "Introductory Statement to the Press Conference (With Q\&A), May 5th, 2011." https://www.ecb.europa.eu/press/pressconf/2011/html/is1 10505.en.html

Verdun, A., and J. Zeitlin. 2018. "Introduction: The European Semester as a New Architecture of EU Socioeconomic Governance in Theory and Practice." Journal of European Public Policy 25 (2): 137-148. doi:10.1080/13501763.2017.1363807.

Wilde, P. D. 2011. “No Polity for Old Politics? A Framework for Analyzing the Politicization of European Integration." Journal of European Integration 33 (5): 559-575. doi:10.1080/07036337.2010.546849.

Zürn, M. 2016. "Opening up Europe: Next Steps in Politicisation Research." West European Politics 39 (1): 164-182. doi:10.1080/01402382.2015.1081513.

Draghi, M., and V. Constâncio. 2015. "Introductory Statement to the Press Conference (With Q\&A)." https://www.ecb.europa.eu/press/pressconf/2015/html/is150903.en.html 